
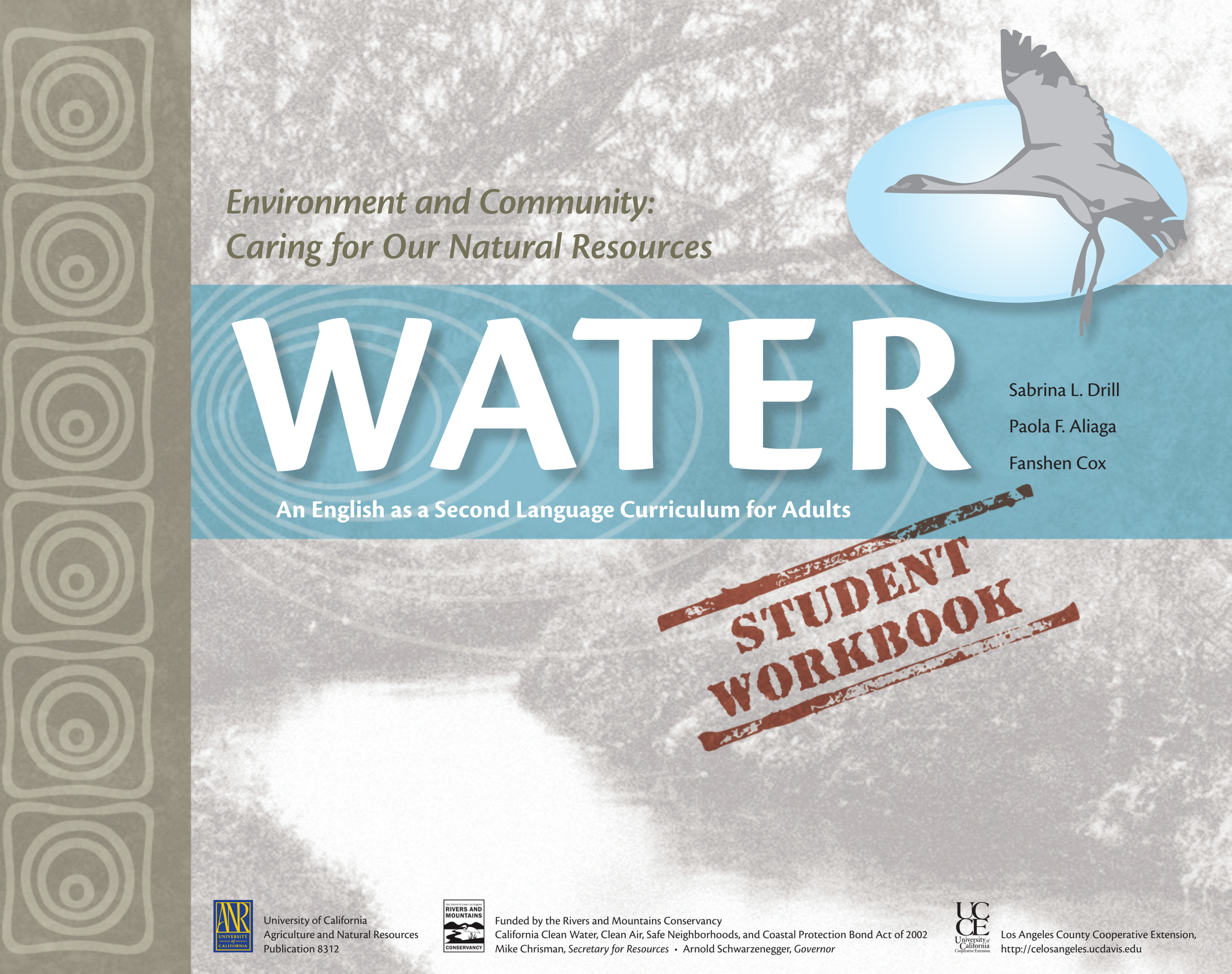


\section{Environment and Community:}

Caring for Our Natural Resources

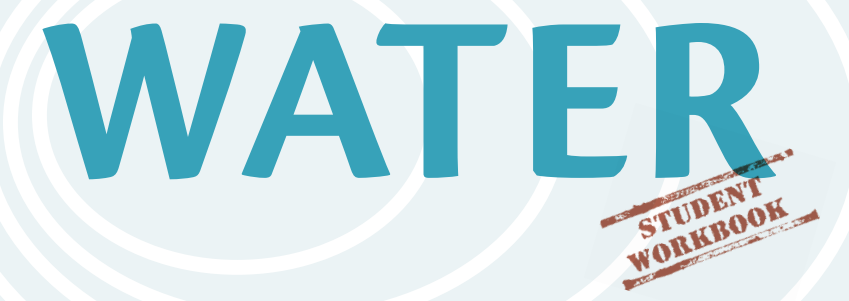

An English as a Second Language Curriculum for Adults

Sabrina L. Drill • Paola F. Aliaga • Fanshen Cox 
To order or obtain ANR publications and other products, visit the ANR Communication Services online catalog at http://anrcatalog. ucdavis.edu or phone 1-800-994-8849. You can also place orders by mail or FAX, or request a printed catalog of our products from

\section{University of California}

Agriculture and Natural Resources

Communication Services

6701 San Pablo Avenue, 2nd Floor

Oakland, California 94608-1239

Telephone 1-800-994-8849

(510) 642-2431

FAX (510) 643-5470

E-mail: danrcs@ucdavis.edu

Publication 8312

ISBN-13: 978-1-60107-556-7

Design by Robin Walton.

(C)2010 The Regents of the University of California

Division of Agriculture and Natural Resources

All rights reserved.

No part of this publication may be reproduced, stored in a retrieval system, or transmitted, in any form or by any means, electronic, mechanical, photocopying, recording, or otherwise, without the written permission of the publisher and the authors.
The University of California prohibits discrimination or harassment of any person on the basis of race, color, national origin, religion, sex, gender identity, pregnancy (including childbirth, and medical conditions related to pregnancy or childbirth), physical or mental disability, medical condition (cancer-related or genetic characteristics), ancestry, marital status, age, sexual orientation, citizenship, or status as a covered veteran (covered veterans are special disabled veterans, recently separated veterans, Vietnam era veterans, or any other veterans who served on active duty during a war or in a campaign or expedition for which a campaign badge has been authorized) in any of its programs or activities. University policy is intended to be consistent with the provisions of applicable State and Federal laws.

Inquiries regarding the University's nondiscrimination policies may be directed to the Affirmative Action/Staff Personnel Services Director, University of California, Agriculture and Natural Resources, 1111 Franklin Street, $6^{\text {th }}$ Floor, Oakland, CA 94607-5201, (510) 987-0096. For information about ordering this publication, telephone 1-800-994-8849.

\section{UCER}

REVIEWED This publication has been anonymously peer reviewed for technical accuracy by University of California scientists and other qualified professionals. This review process was managed by the ANR Associate Editor for Natural Resources.

web-1/10-SB/RW 


\section{LESSON 4: WATERSHEDS}

LESSON 1: WATER, WATER EVERYWHERE

Objectives. . . . . . . . . . . . . . .

Exercise 1: Water Proverbs . . . . . . . . . . . . . 1

Exercise 2: Synonyms and Definitions . . . . . . . . 1

Exercise 3: Body of Water . . . . . . . . . . . . 2

Exercise 4: Water Poems ... . . . . . . . . . . . 3

Exercise 5: Make Your Own Poem. . . . . . . . . . . . 4

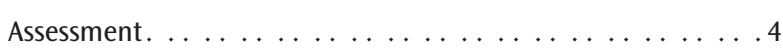

Expansion. ...................

\section{LESSON 2: WATER CONSERVATION}

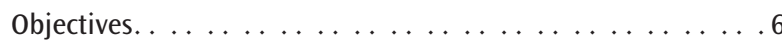

Exercise 1: Key Vocabulary . . . . . . . . . . . .6 6

Exercise 2: The Water Planet . . . . . . . . . . . . 6

Exercise 3: How Much Water Do We Use? . . . . . . . . . 6

Exercise 4: Water Tips, Rebates, and Programs ... . . . . 7

Assessment. . . . . . . . . . . . . . . . 9

Expansion. ....................

\section{LESSON 3: WATER IN YOUR COMMUNITY}

Objectives. . . . . . . . . . . . . . . . . 10

Exercise 1: Key Vocabulary . . . . . . . . . . . . . 10

Exercise 2: Map Features . . . . . . . . . . . . . . 10

Exercise 3: Changing Rivers. . . . . . . . . . . . . . 11

Exercise 4: The Los Angeles River: Vocabulary in Context . . . 12 Exercise 5: The Los Angeles River: Comprehension Questions 13 Exercise 6: The Los Angeles River: Reading Passages . . . . . . 15 Assessment. . . . . . . . . . . . . . . . . . . 18 Expansion. . 19 .
Objectives. . . . . . . . . . . . . . . . 20

Exercise 1. Key Vocabulary . . . . . . . . . . . . . . . 20

Exercise 2: Where Does the Water Flow? . . . . . . . . . 20

Exercise 3: What Are Watersheds? . . . . . . . . . . . . 20

Exercise 4: Two Watersheds . . . . . . . . . . . . . . 21

Exercise 5: Protecting Our Watersheds... . . . . . . . 23

Assessment. . . . . . . . . . . . . . . 23

Expansion. . . . . . . . . . . . . . . . 24

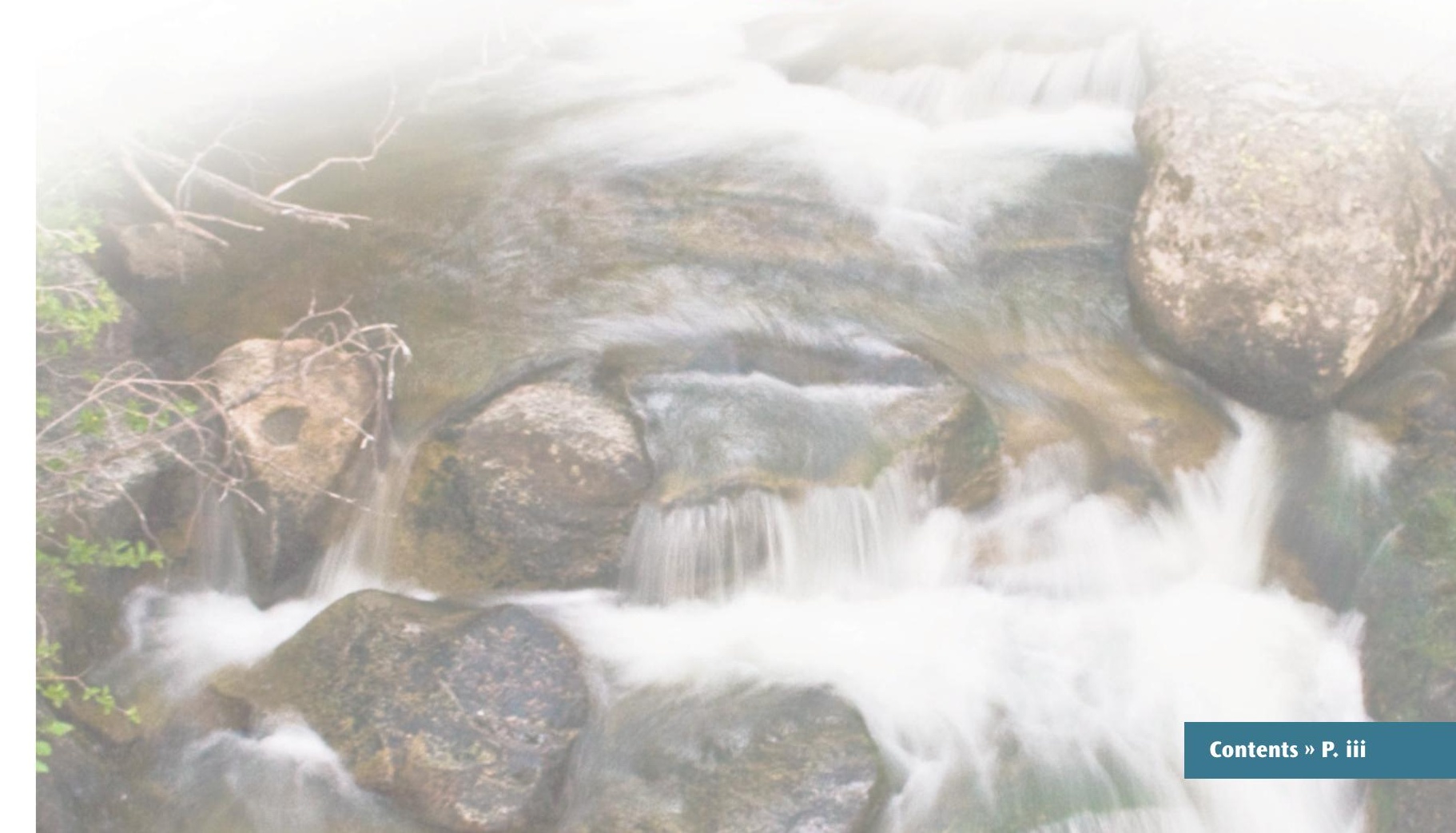

\section{LESSON 5: REDUCING WATER POLLUTION}

Objectives. . . . . . . . . . . . . . . . . . . . 25

Exercise 1. Key Vocabulary . . . . . . . . . . . . . . . 25

Exercise 2: Two Causes of Water Pollution. . . . . . . . . . 25

Exercise 3: Two Causes of Water Pollution: Scanning. . . . . . 26

Exercise 4: Sewers and Storm Drains. . . . . . . . . . 26

Exercise 5: Is This a Sewer or a Storm Drain? . . . . . . . . . 27

Exercise 6: Los Angeles Storm Drains. . . . . . . . . . . . 27

Exercise 7: Reducing Pollution. . . . . . . . . . . . 28

Exercise 8: Who Can You Call For Help? . . . . . . . . . . 30

Assessment. . . . . . . . . . . . . . . . . 30

Expansion. . . . . . . . . . . . . . . . . . . . . . 31

GLOSSARY . . . . . . . . . . . . . . . . 32 


\section{Water, Water Everywhere}

\section{Objectives}

To acquire and share words about water

To share and analyze proverbs that use water words

To define

"synonym"

To use a

thesaurus to

find synonyms

\section{Exercise 1: PROVERBS}

A proverb is an expression that many people use and understand. Proverbs give advice or opinions about how to live. Write any proverbs you know in English or your native language that include the word "water" or something having to do with water:

\section{Exercise 2: SYNONYMS AND DEFINITIONS}

For the words below, write a definition. If you can find a synonym for the word, include that as well.

proverb:

synonym:

antonym:

thesaurus:

saltwater: freshwater:

lake:

river:

stream:

creek:

lagoon:

ocean:

sea:

pond:

spring $(n)$ :

brook:

marsh:

flood $(n)$ :

shed $(v)$ :

drain $(v)$ :

soak:

watershed:

vital:

Name three things that are vital to you: 


\section{Water, Water Everywhere}

\section{Notes}

\section{Exercise 3: BODY OF WATER}

Body of water:

Which words in the vocabulary list are bodies of water (write them in the boxes below)? Can you think of any more?

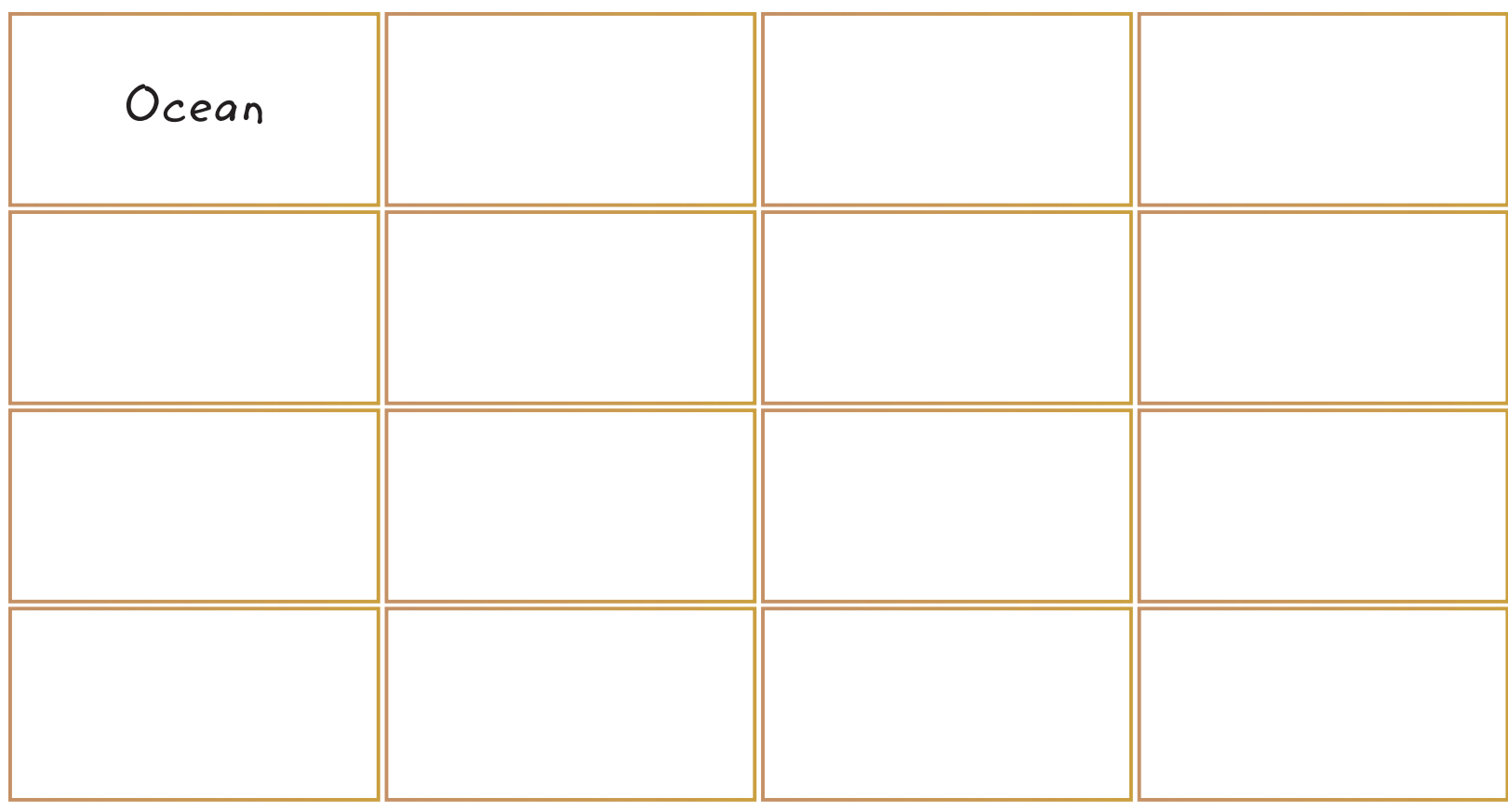




\section{Water, Water Everywhere}

\section{Notes}

2. In "Water" what are the antonyms of "steady" and "old"?

3. Who or what is speaking in "Untitled"? Is it a different speaker from "Seasons of Water"?

4. Make a list of the words from the poems that are related to water:

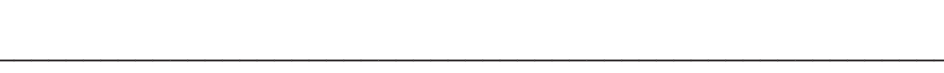

\section{Untitled}

I flow from the mighty mountain down through the magic of moss, mist and forest.

I flow through mighty desert, fire and rain

through cool shade and burning sun.

I flow through beautiful places, ugly places

night and day, under suns and moons.

I flow through disaster and magnificent glory

precious moments and hated past.

I flow through life and study it.

I protect life along with taking it.

I see all and yet I am only a river,

strong and free.

Lauren Anderson, Age 11

Watsonville, California

National Finalist,

2006 River of Words Contest

(c) River of Words
Seasons of Water

Winter

I am the soft, white snow you play in.

I am the steam that rises from your hot cocoa on a cold day.

Spring

I am the gentle shower you dance in.

I am the glistening dewdrops on a crisp, clear morning.

Summer

I am the refreshing mountain pool you splash in.

I am the splat of a water balloon on your back.

Fall

I am the icy cold rain that keeps you inside for recess.

I am the pitter, patter that hits the window when you are curled up beside the fire.

I am the water of your life.

Katy Wilson, Age 9

Collegedale, Tennessee

National Finalist

2006 River of Words Contest

(c) River of Words

\section{Water}

Water is as steady as thoughts

as unstable as a child's first steps

as old as time

as fresh as life

as mysterious as dreams

Amanda Ditmore, Age 9

Berkeley, California

National Finalist

2006 River of Words Contest

(c) River of Words 


\section{Notes}

\section{ASSESSMENT}

Now that you have completed this lesson, can you answer all of these questions in English?

1. What new water words did you learn?

2. What can you find in a thesaurus?

3. Name three synonyms for "vital."
4. Name three things that are vital to human life.

\section{EXPANSION}

\section{Writing}

1. "My Favorite Body of Water"

Close your eyes and think about your favorite river, ocean or other body of water for about 5 minutes (if you can't think of one, create the ideal one). When you open your eyes, write down everything you remember about that place. Describe it so well that if someone reads what you wrote, they will feel like they are standing in front of that body of water. If you prefer, you can write it in the form of a poem. When you are finished, read it to your classmates.

\section{Water in the Media}

While studying all about water, pay attention to television and radio programs or newspaper articles or Web sites that talk about water or bodies of water. Whenever you hear or read anything about water, write it down and tell the teacher and class all about it. For example, while writing this curriculum, there was a big event for cleaning up the Los Angeles River, sponsored by Friends of the Los Angeles River. This is something that you can share with the class, your teachers and friends. 


\section{Family Activity}

1. Water Use

Have everyone in your family observe his or her own water use. How many times in one day do you (and your family members) turn on the faucet, drink water or wash with water? Try to use as much English at home as possible to complete the exercise.

\section{River of Words}

River of Words (ROW) is an educational nonprofit organization based in Berkeley, California, promoting cultural and environmental literacy through the arts and cultural exchange.

ROW conducts an annual international poetry and art contest for youth, in affiliation with the Library of Congress Center for the Book. Through its teacher workshops, curriculum materials, exhibitions, and publications, ROW encourages students around the world to explore their own communities and imaginations-weaving in natural and cultural history - and then to synthesize what they have learned and observed into line and verse.

River of Words was cofounded in 1995 by United States Poet Laureate (1995-97) Robert Hass and writer Pamela Michael. In 2003 River of Words opened one of the only art galleries in the world devoted exclusively to the work of children, called "Young at Art."
For information or to order art prints, calendars, or ROW art and poetry, contact:

River of Words, PO Box 4000-J, Berkeley, CA 94704;

tel: 510-548-POEM (7636); Web site, www.riverofwords.org.

\section{Search the Web}

Many Web sites include poems and proverbs about water. Teach your children (or other young people you know) how to search the World Wide Web (or maybe they can teach YOU!). A good place to begin is www.google.com and type in "poems or proverbs about water."

4. Web Sites about Water

There are many other Web sites dedicated to teaching more about water. Three more to investigate are given below. How many more can you find

- World Water Day, http://www.worldwaterday.org

- University of California World Water Resources Archives, http://www.lib.berkeley.edu/WRCA

- Water Education Foundation, http://www.watereducation.org

\section{Grammar}

Practice making yes-no questions and short answers by interviewing people about the water in their countries. 


\section{Water Conservation}

\section{Objectives:}

To compare the availability of

freshwater on the earth to the need

for freshwater

To define

"conservation"

To identify and

share ways to

conserve water

\section{Exercise 1: KEY VOCABULARY}

drinkable:

saltwater:

freshwater:

gallon:

conserve:

average:

faucet:

leak:

leaky:

\section{Exercise 2: THE WATER PLANET}

Which proverb from Lesson 1 describes that there is very little freshwater for us to drink, even though the earth is mostly water?

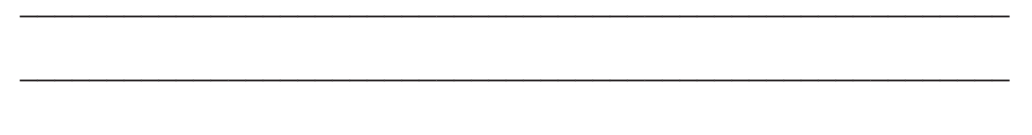

\section{Exercise 3: HOW MUCH WATER DO WE USE?}

Match the number of gallons of water you think it takes to complete each activity. Write the letter of the typical number of gallons used in the blank provided.

\section{ACTIVITY}

\section{Typical number of gallons used}

__ Taking a bath or shower

_ Watering the lawn and yard

_ Washing the dishes by machine or hand

__ Washing clothes

__ Washing the car

__ Brushing your teeth

_ Cooking

_ Drinking

__ Flushing the toilet (once)

__ Leaking toilet (per day)
A. $35-50$ gallons

B. $1 / 2$ gallon

C. 4-7 gallons

D. 180 gallons

E. 50 gallons

F. 8-13 gallons

G. 5-10 gallons

H. 9-12 gallons

I. 60 gallons

J. 2-5 gallons 


\section{Notes}

\section{Exercise 4: WATER TIPS, REBATES, AND}

PROGRAMS FOR EAST LOS ANGELES

1. Referring to the tips on the next page, name three things you can do in the bathroom to save water.

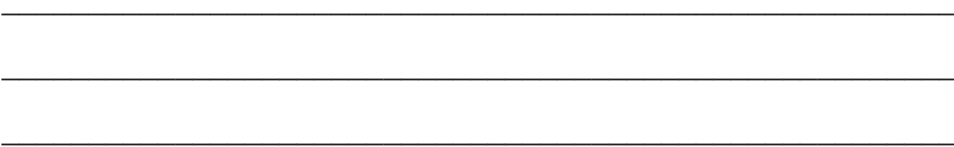

2. Name three things you can do in the kitchen to save water.

3. According to the tips below, when is the best time to do laundry?

4. Which saves more water: washing your car yourself or taking your car to a car wash? Why?

\section{According to the tips below, how can you get a rebate for the} following amounts:

$\$ 100.00$ :

$\$ 150.00$ :

$\$ 175.00$ :

$\$ 75.00$ :

6. Did you learn new ways to conserve water by reading these tips? Why or why not?

7. List at least three other ways you can think of (or have already used) to conserve water.

Now read the tips on the next page. Then go back to the questions and see how many you can answer. 


\section{WATER-WISE TIPS, REBATES, AND PROGRAMS FOR EAST LOS ANGELES}

\section{Water-Wise Tips}

(2) Take shorter showers; use less water in your baths.

(2) Don't leave the faucet on when you brush your teeth or your hair.

(2) Don't leave the water on when you wash dishes. Instead, fill the sink or wash tub to wash and rinse dishes.

(2) When you are waiting for water to heat up, collect the cold water and use it for plants.

(2) Check all faucets for leaks and replace any leaky washers.

(2) Is your toilet leaking? Put a drop offood coloring in the tank and don't flush. If the water in the bowl changes color, you have a leak.

(2) When you use the dishwasher or do laundry, wait until you have a full load.

(0) Don't leave the hose running when you wash your car. It is better to take your car to a car wash. They usually use less water and often recycle or throw the dirty water away in the proper place.

(2) Use a broom instead of water to clean up your driveway and walk ways.

(2) Replace your showerheads and toilets with low-flow heads and low-flush models (they might be free!).

\section{Rebates and Programs}

City of Los Angeles Department of Water and Power customers

Rebate up to $\$ 100.00$ when you buy an ultra-low-flush toilet. You may even be able to get a free toilet! For more information call (800) 544-4498 or visit the Los Angeles Department of Water and Power (LADP) Web site,www.ladwp.com.

Rebate up to $\$ 150.00$ if you buy a high-efficiency washing machine. Call (800) 203-7380 or visit www.ladwp.com to get an application.

Get free trees! For more information call (800) 473-3652 or visit www.ladwp.com.

\section{City of Monterey Park Water Department:}

Get FREE ultra-low-flush toilets each spring. For more information call (626) 307-1293, or visit the Web site,www.waterprograms.com.

\section{East Los Angeles California Water Service Group}

FREE water-saving plumbing fixtures, like low-flow showerheads, kitchen faucets, and hose nozzles. For more details contact your local office (on your bill) or visit the California Water Service Company Web site, http://www.calwater.com/WaterSavingPlumbingFixtures.html.

Rebate of $\$ 75.00$ on an ultra-low-flush toilet. Call the Oldtimers Foundation at (877) 732-2830 for more information.

Get a $\$ 175.00$ rebate on a high-efficiency clothes washer through the Central Basin Municipal Water District. Call the Oldtimers Foundation at (877) 732-2830 for more information, or visit http://www.centralbasin.com or www.calwater.com. 


\section{ASSESSMENT}

1. How much of the planet consists of water?

2. How much of the planet's water is drinkable?

3. What does "conserve" mean?

4. How did you conserve water in your country?

5. How can you conserve water at home?

\section{EXPANSION}

\section{Writing}

\section{Water Conservation}

Write an essay about water conservation. In your introduction, talk about how little water there is available for humans to use on the planet and why it is important to conserve water. In the body, write three paragraphs: each one should present a different option for conserving water. In the conclusion, tell your reader what the future might be like if we don't conserve water.

\section{How Much Water Do You Use?}

For the next 24 hours, observe and write down everything you do that requires water.

$$
\begin{array}{ll}
\text { Example: } & \text { 12:35 P.м.: Washed my hands before lunch. } \\
& \text { 12:40 P.M.: Drank water with my lunch. } \\
\text { 1:00 P.M.: Washed the dishes from lunch. }
\end{array}
$$

When you are finished, think about these questions: How many times in 24 hours did you use water? Was it more or less than you expected? Do you think you use more or less water than the other students and teacher? Read your notes again and write a paragraph about what it was like to do this exercise. Compare your answers with your classmates and teacher in your next class. Compile the results, then on the internet to compare your class's average use to water use in the United States or in your native country.

\section{Family Activity}

Do Exercise 2, "Water Planet," with members of your family, using candy, pizza, a tortilla, a dumpling or any food you like.

\section{Guest Speaker}

Find a professor on your campus who is involved with conservation (possible departments to search for one include earth science, life science, civil engineering, and geology). Prepare interview questions and ask him/her to visit the class. Take notes during the interview then summarize them in an essay.

\section{Grammar}

Look at Exercise 3 again and observe the use of the gerund as the subject of the sentence. Think of other ways you use water and make a statement about it using the gerund. 


\begin{tabular}{ll} 
Objectives & Exercise 1: KEY VOCABULARY \\
To get and give & map features: \\
directions & north: \\
To guess & south: \\
vocabulary & east: \\
definitions using & west: \\
context clues & flood: \\
To compare the & native: \\
present state of & agriculture: \\
the Los Angeles & aqueduct: \\
River with the & concrete: \\
past & channelization: \\
\hline To analyze how & desirable: \\
and why the Los & soak:
\end{tabular}

\section{Exercise 2: MAP FEATURES}

1. Find your school on the map.

2. Find the area where you live. What roads could you take to get from your house to school? Angeles River protect the Los
3. Looking at the map, can you find some rivers? How do you know they are rivers?

4. What rivers are closest to this school?

5. What communities do these rivers run through? Where do the rivers meet the ocean?

6. Some of our main freeways are built along the rivers. Why do you think some freeways run along the sides of rivers? 


\section{Water In Your Community}

\section{Notes}

\section{Exercise 3: CHANGING RIVERS}

When were the pictures below taken?

What are the similarities in the pictures?

What are the differences?

Why were there so many changes?
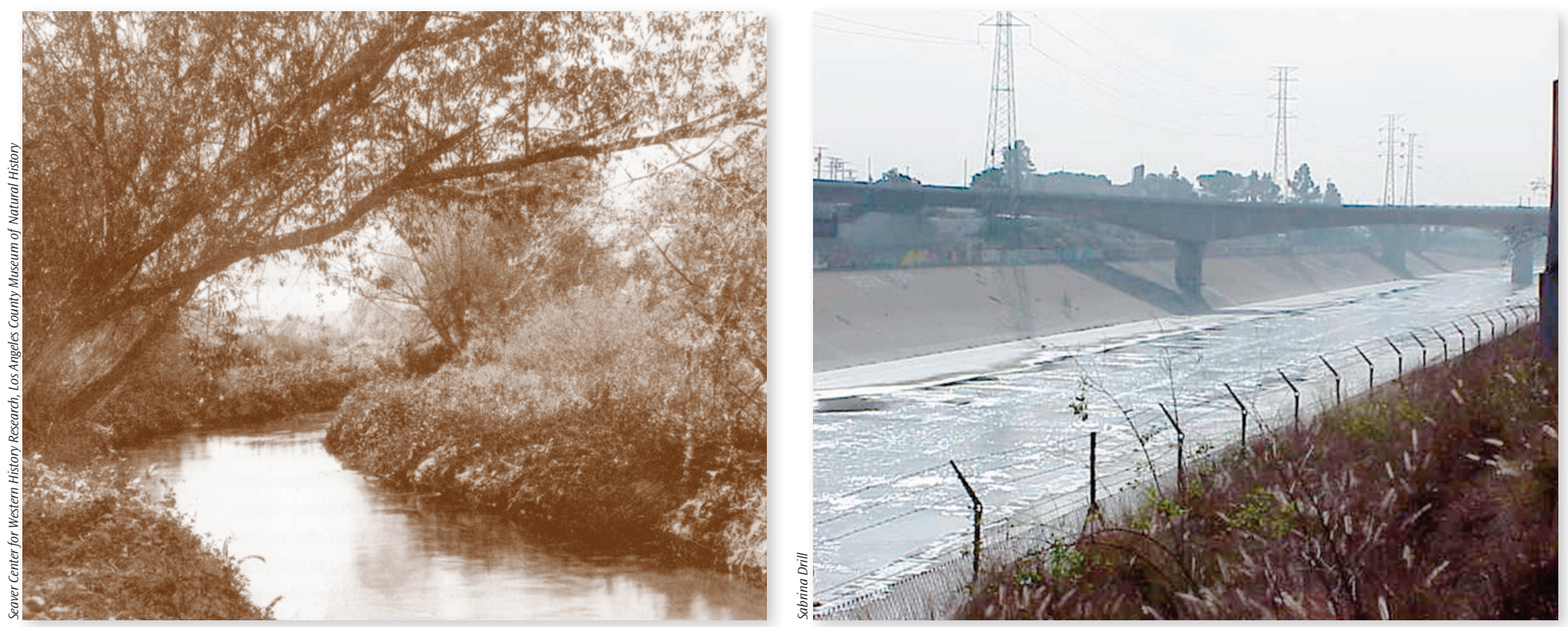

The Los Angeles River IN THE 1900s.

THE Los ANGeles RIVER IN A CONCRETE CHANNEL NEAR DOWNTOWN, 2008. 


\section{Notes}

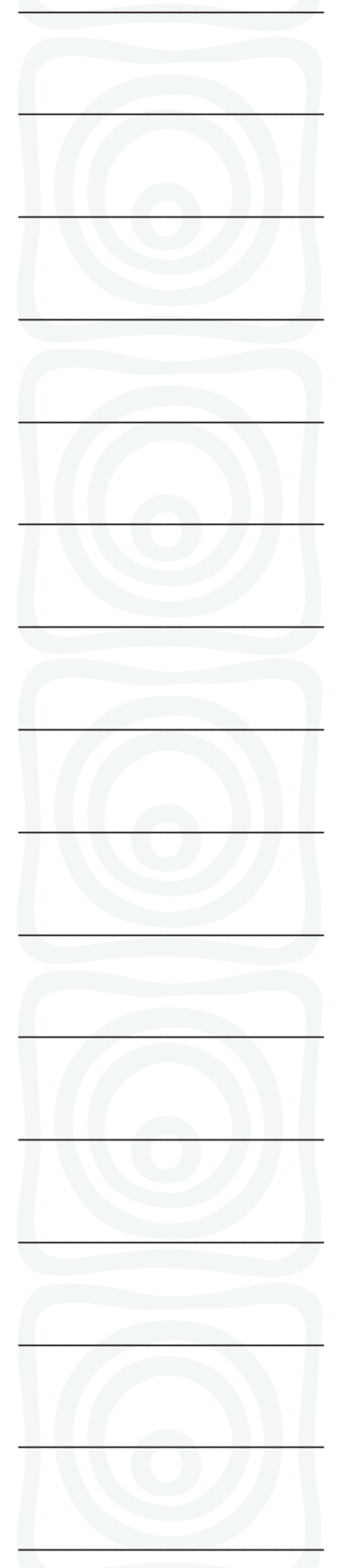

\section{Exercise 4: THE LOS ANGELES RIVER}

Choose the answer that best defines the word in bold.

Example: When it rained a lot in New Orleans, there was a flood.
A. Too much wind
B. Too much heat
C. Too much snow
D. Too much water

Which words gave you clues about "flood"?

1. "The Los Angeles River flowed across large areas of Los Angeles."
A. To stop
B. To go from one place to another
C. To throw away
D. To listen

Clues:

2. "... one of the first Spaniards to visit Los Angeles ..."
A. People from Mexico
B. People from Spain
C. People from Los Angeles
D. People from America

Clues:
3. "The native people of Los Angeles, the Chumash and Tongva, lived along the river."
A. The trees
B. The river
C. The first people
D. The people who visit a place

Clues:

4. “.. . Los Angeles was an agricultural village ... large areas of cornfields, orange groves, vineyards and cattle* ranches..." (Note: "cattle" means "cows.")
A. Los Angeles had many farms
B. Los Angeles had a lot of beaches
C. Los Angeles had a lot of buildings
D. People in Los Angeles ate oranges Clues:

5. “. . . the Treaty of Guadalupe Hidalgo made California part of the United States.
A. Treatment
B. War
C. Agreement
D. Government

Clues: 


\section{Notes}

6. "The Los Angeles Aqueduct brought water from the Owens Valley to Los Angeles."
A. Something that transports water
B. Something that transports people
C. Something that transports valleys
D. Something that transports cars

Clues:

7. "... some of the most desirable land was along the rivers."
A. Likable
B. Disgusting
C. Decided
D. Worst

Clues:

8. "In areas with concrete*-lined channels, no water soaks into the ground...." (Note: "concrete" refers to a solid building material.)
A. Comes out
B. Goes in
C. Dries up
D. Stays on top

Clues:
Exercise 5: THE LOS ANGELES RIVER: COMPREHENSION QUESTIONS FOR EXERCISE 6

Questions for Passage I (p. 15)

1. Describe the Los Angeles River before Europeans came to Los Angeles.

2. Who lived here at that time?

3. When and why did the area change?

4. What kind of village was Los Angeles?

5. Name four things that happened in the $1820 \mathrm{~s}$. 


\section{Notes}

Questions for Passage II (p. 16)

1. What happened in 1848 ?

2. Where did people in Los Angeles get their water from?

3. What important event happened in 1876 ? How did this affect the Los Angeles River?

4. Name three changes that happened in the area at that time.

5. How did engineers solve the problem of getting enough water to everybody?
6. Complete the following chart about the three aqueducts.

\begin{tabular}{|c|c|c|}
\hline YEAR & 1913 & \\
\hline NAME & & \\
\hline BEGINS IN & & Colorado River \\
\hline
\end{tabular}

\section{Questions for Passage III (p. 17)}

1. What are two things the Los Angeles County government spends a lot of money on?

\section{What is the land like near the river?}

3. What happens to floodplains when it rains a lot?

4. Why did the government build concrete channels in the LA River?

5. What are the benefits and drawbacks of channelization? 


\section{Exercise 6: THE LOS ANGELES RIVER:}

\section{READING PASSAGES}

Your teacher will ask you to read one of the following three passages. When you are finished, you will sit with other students who read the same passage and compare your answers. Then you will share with students who read different passages.

\section{Early Days}

Before Europeans came to Los Angeles, the Los Angeles River flowed across large areas of the flat Los Angeles plain. There were large marshes and tree-lined streams.

Father Juan Crespi, one of the first Spaniards to visit Los Angeles in the early 1800s, wrote that the forest along the river was "green and lush." The native Chumash and Tongva lived along the river and used the water for many things. They made paths along the river to move from the mountains to the ocean.

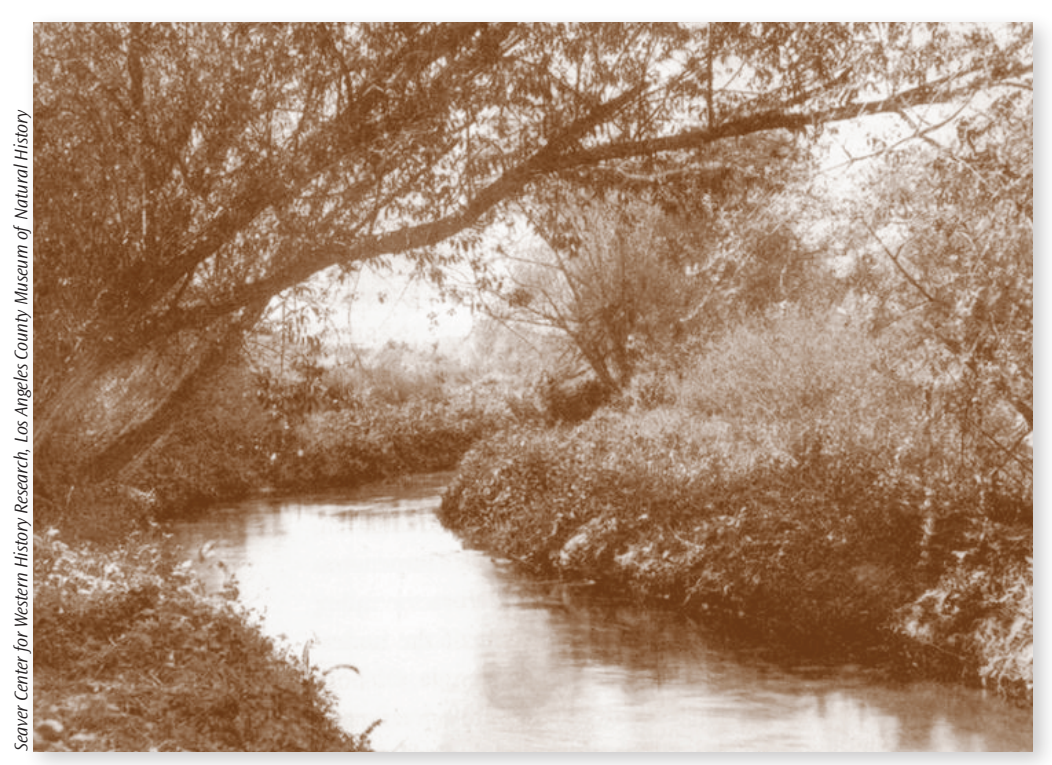

The Los Angeles River in the 1900S.
The first Spaniards to build their homes in the area were priests. They built missions along the Los Angeles River in the San Fernando Valley and along the San Gabriel River in San Gabriel. Later, other Spaniards founded El Pueblo de la Reina de Los Angeles, or The City of the Queen of the Angels, along the sides of the river (near what we call "downtown" today).

At that time, Los Angeles was an agricultural village and the rivers provided water for large areas of cornfields, orange groves, vineyards, and many cattle ranches.

In the 1820s, California became part of Mexico, and agriculture in the Los Angeles area continued to expand. People came here from all over Europe. Several American and French settlers came here and began farming. Eventually the area around downtown Los Angeles became one of the most important wine-producing regions in North America. 


\section{Notes}

\section{Los Angeles Grows}

In 1848, the Treaty of Guadalupe Hidalgo made California part of the United States. At this time, Los Angeles was still an agricultural community that got water from the Los Angeles River. Then the transcontinental railroad was built in 1876 and changed Los Angeles forever.

Because of the railroad, people from other parts of the United States could more easily come to this wonderful, sunny climate. The population of Los Angeles tripled from 33,881 in 1880 to 101,454 in 1890! Many farmers sold their land to home builders. The farms moved away from the city center and went to the north and south along the rivers.

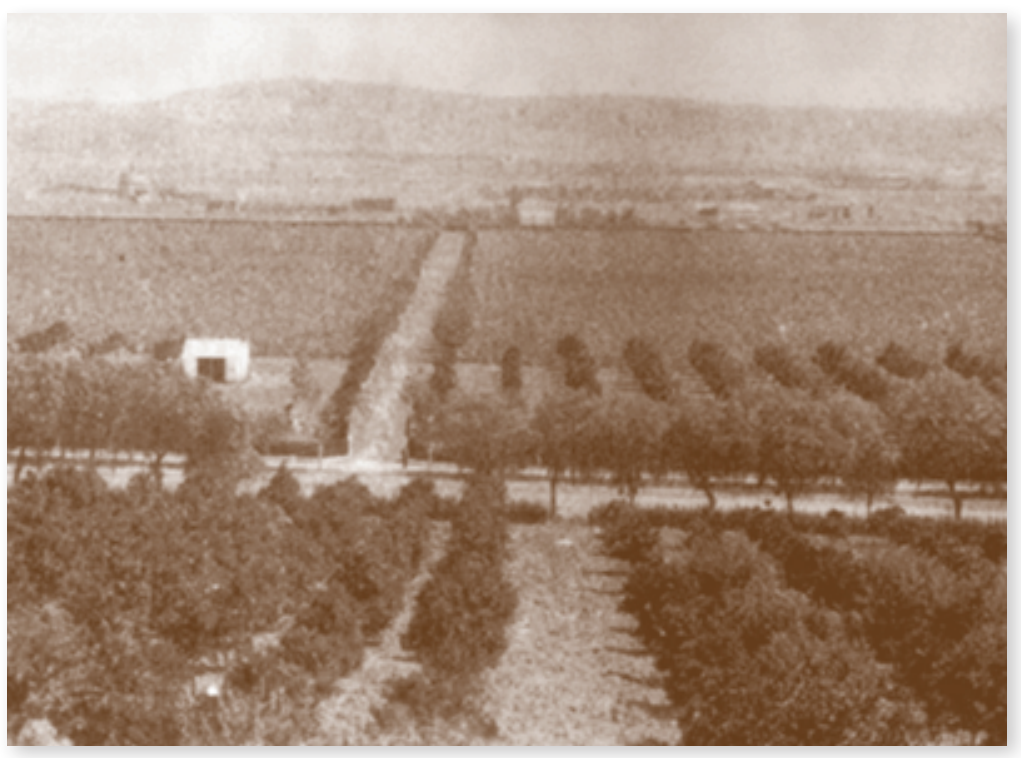

ORCHARDS AND VINEYARDS NEAR LINCOLN HEIGHTS, MID-1900s.
The Los Angeles River could not provide the bigger city and farms with enough water. One of the most difficult engineering projects in the twentieth century began at this time. Three huge canals, or aqueducts, were built to bring water to Southern California from other bodies of water.

The Los Angeles Aqueduct was completed in 1913, bringing water from the Owens Valley to Los Angeles. In 1941 the Colorado River aqueduct was completed, bringing water from the Colorado River to Los Angeles and Southern California. In the 1960s, the California Aqueduct was built, bringing water from the Feather River in Northern California to Los Angeles and the rest of Southern California.

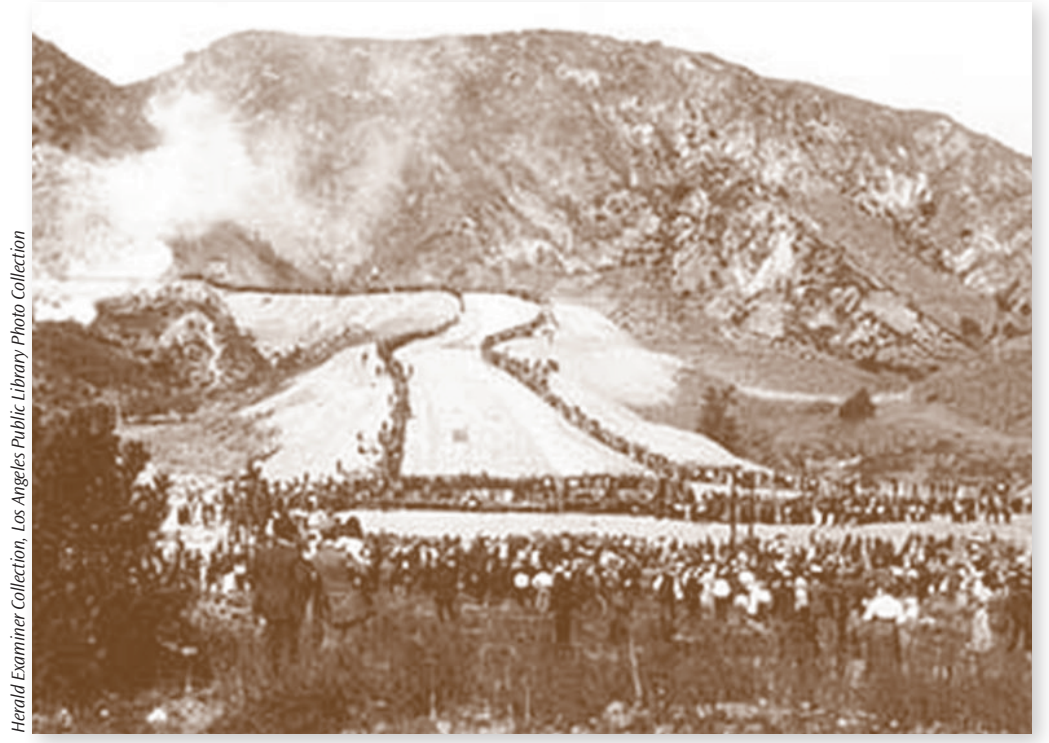

The Los Angeles Aqueduct entering the San Fernando Valley, 1913. 


\section{Notes}

\section{Trying to Control the River}

The City of Los Angeles government spends millions of dollars to get water into Los Angeles. It also spends millions of dollars trying to get water out when it rains. It usually rains only for a short time in Los Angeles, but when it rains, it rains a lot. In fact, the Los Angeles River might be dry in the summer, but it can rise several feet during a storm

A large part of Los Angeles is very flat. Sometimes when it rained a lot, the river traveled across this flat land and flooded a very large area called the floodplain. Floods were very unpredictable; nobody knew exactly when they would come. On New Year's Day 1934, a very large flood washed away bridges and houses and killed over 80 people.

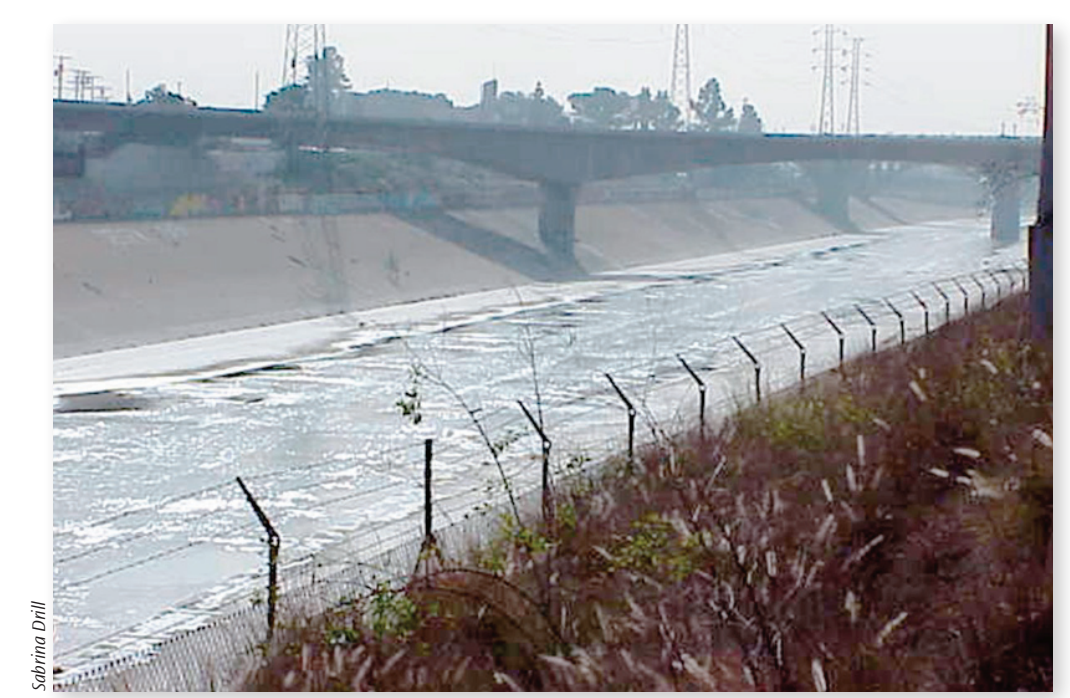

THE Los ANgeles River IN A CONCRETE CHANNEL NEAR DOWNTOWN, 1990 s.
After this, the government of Los Angeles decided to build huge channels made from concrete (see the picture at left) to hold the Los Angeles River. This is called channelization. These channels reduced the danger from flooding and kept the residents of Los Angeles safe from floods.

Unfortunately when the Los Angeles River was channelized, we lost many of the good things about the river. For example, plants cannot grow through the concrete. Without plants, the birds, fish, and other animals that used to live in the river cannot survive. Also, plants can help take some of the chemicals and other pollution out of the river. As you can see, there are benefits and drawbacks to channelization. 


\section{Notes}

ASSESSMENT

3. Where do people in Los Angeles get their water?

$$
-
$$

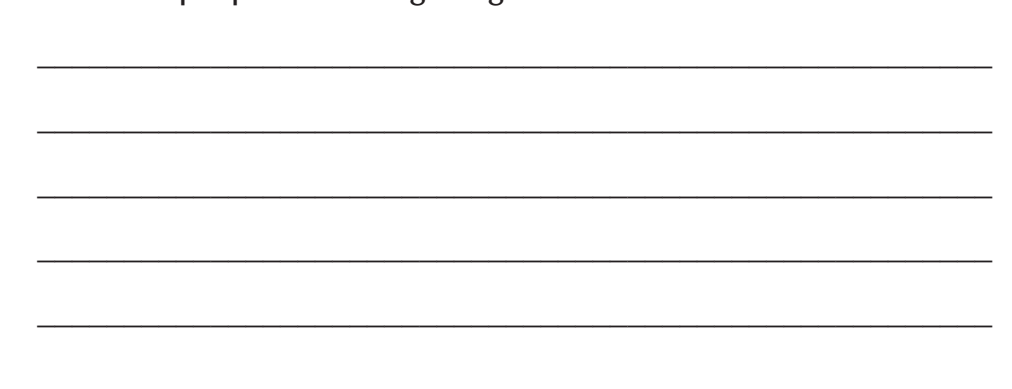

1. Name two or more rivers or streams near your school, neighborhood, or community.

2. Why do many place names in California come from Spanish words?

\section{Why does the Los Angeles River have concrete channels?}

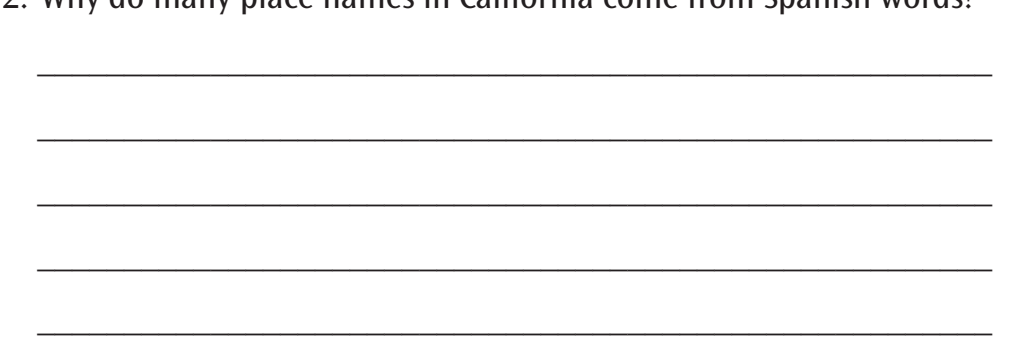

$$
\underline{\bar{P}}
$$

5. What are the benefits and drawbacks of channelization?

\section{What are the benefits and drawbacks of channelization?}
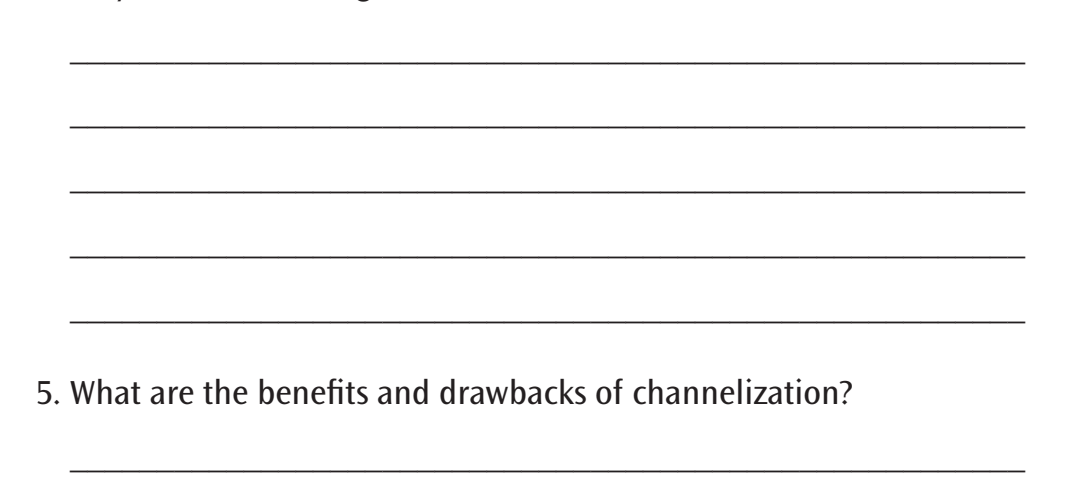


\section{Notes}

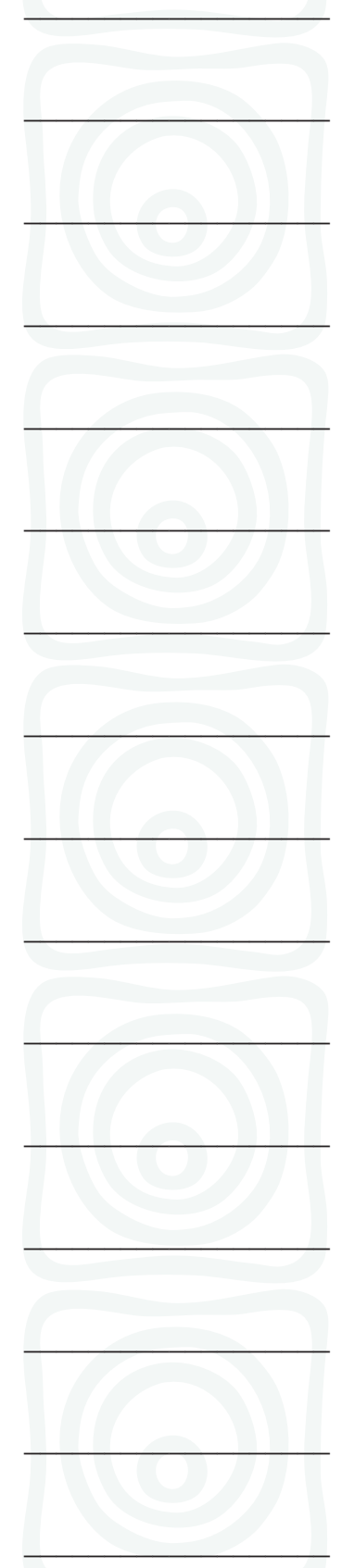

\section{EXPANSION}

\section{Writing}

Find the river or body of water nearest your home or school. Take your journal there and write about everything you see. Are there concrete channels? If so, what do they look like? Are there birds, animals, and plants there? Do you think in a storm that the river could rise? How much water is there? Are you surprised? Did you think there would be more or less?

\section{Family Activity}

1. "Daylighting" is when people dig up concrete and asphalt to find streams underneath. People in many cities are daylighting. To find more information, go to www.google.com and search for "stream daylighting" and the name of your city or visit www.urbancreeks. org. You can also find out about urban streams by going to www. northeasttrees.org.

2. FOLAR. In many places, neighbors have decided to form groups to take care of their local river. Often these are called "Friends of" groups. Use the Internet to search for "friends" and the name of your local river. One example is Friends of the LA River (FOLAR). This is a group of people who want to help clean up the Los Angeles River so that everyone can enjoy it. Every year FOLAR has La Gran Limpieza (ask a Spanish speaker in your class to translate), and thousands of people help clean up different parts of the river. Get more information from their Web site, www.folar.org, or by calling 323-223-0585. If the Los Angeles River is not in your community, see if you can find information about the bodies of water near you.

\section{Guest Speaker}

Ask your children, other family members, or your children's teacher if they know of someone who has more information about the water in your community. Schedule an appointment to have him or her come in and talk to your class.

\section{Grammar}

Review "used to" and "didn't use to" to talk about habits in the past. Then ask a classmate questions what the Los Angeles River used to be like and what it is like now. 


\section{Objectives:}

To name the characteristics of a "watershed" To determine the connection between you, your community, and the bodies of water in your community

To locate your community watershed

To list ways

of keeping watersheds clean

\section{Exercise 1: KEY VOCABULARY}

watershed:

drain:

floodplain:

chemicals:

polluted:

\section{Exercise 2: WHERE DOES THE WATER FLOW? DESCRIBE YOUR AREA ON A RELIEF MAP}

Use the space below to describe what your school's community looks and feels like on the relief map.

A watershed is

Exercise 3: WHAT ARE WATERSHEDS?

LISTEN AND FILL IN THE BLANKS

What Are Watersheds and Why Are Watersheds Important?

What is a

? A watershed is the area of land

that into a specific

of water (such as a lake, river, or ocean).

When it rains, the water across the land or into the ground. This rainwater and all of the places the rainwater touches before it arrives at a body of water are part of a watershed. Therefore, if the water touches a , building, road, garden, the top of your head, or__ else, those are also parts of the watershed. it flows into. The water that flows from the San Gabriel Mountains the Los Angeles area drains into the Los Angeles River or the San Gabriel River. If the water drains into the Los Angeles River, the water and the land it flows over is called the watershed. If it goes into the San Gabriel River, the water and land that it flows over is called the San Gabriel River watershed.

are watersheds important? Remember, the water in watersheds flows into a body of water. Bodies of water give us water to , wash, and grow food. We also use the water in factories, power plants, and other . Bodies of water also

the water for plants to grow, for fish to in, and for other animals to drink.

If a watershed is , the body of water it flows into might be polluted too. Your watershed is all you. What does look like? 


\section{Exercise 4: TWO WATERSHEDS}

The Los Angeles River watershed covers 831 square miles (2,152 square kilometers). The Los Angeles River begins in the Santa Susanna, Santa Monica, and San Gabriel Mountains. From there it flows down through the center of Los Angeles, where it passes Griffith Park, through the Glendale Narrows, and past downtown, Downey, Compton, and Lakewood. It meets the Pacific Ocean at Queensway Bay in Long Beach.

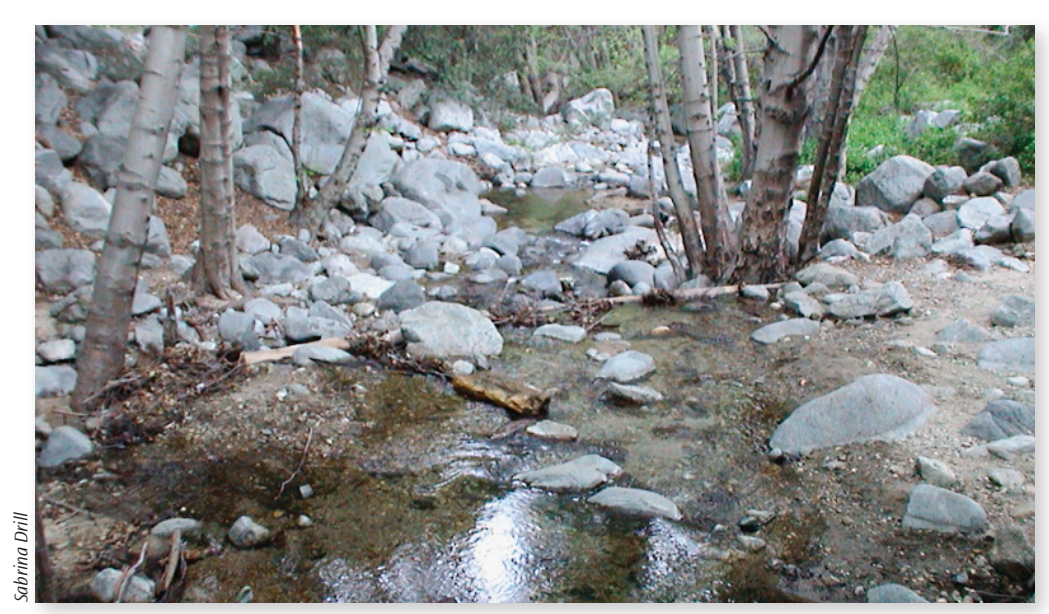

Arroyo Seco, above Pasadena.

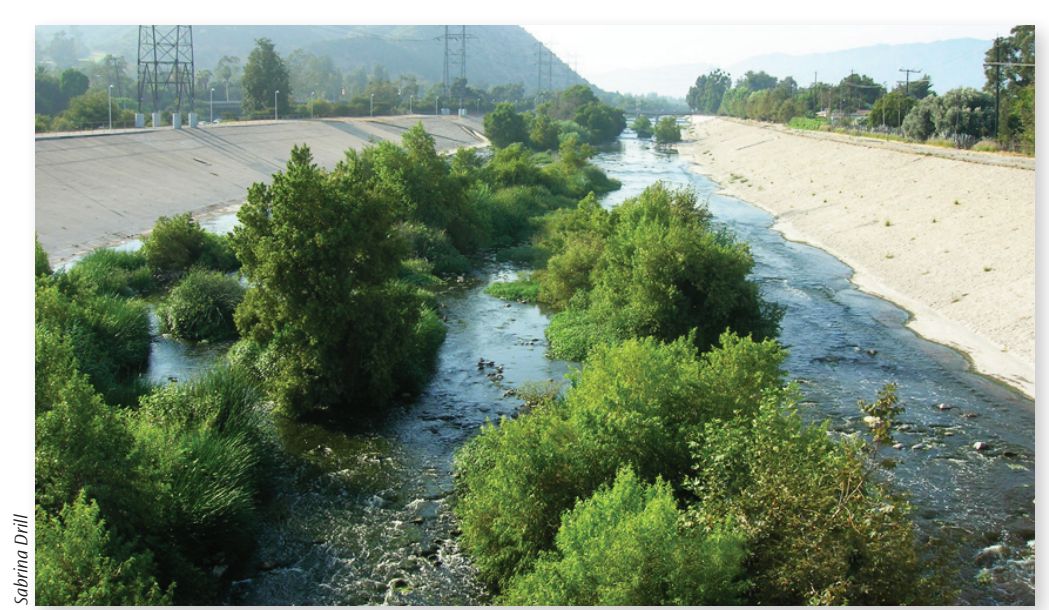

The Los Angeles River in a concrete channel near Griffith Park.
The San Gabriel River watershed includes 635 square miles (1,644 square kilometers). The San Gabriel River starts in the San Gabriel Mountains in Angeles National Forest, to the east of the Los Angeles River. From the east, it flows along the eastern side of the Los Angeles plain, past Azusa, Baldwin Park, El Monte, Santa Fe Springs, Norwalk, Cerritos, and Los Alamitos. It meets the Pacific Ocean at Alamitos Bay between Long Beach and Seal Beach.

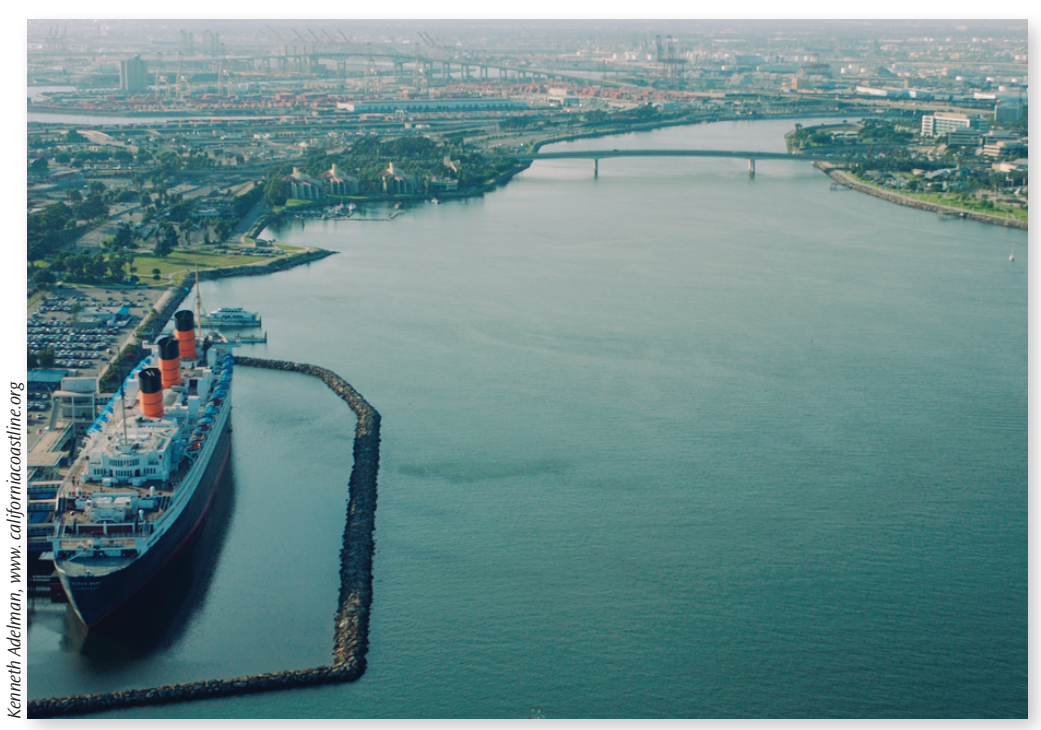

Mouth of the Los Angeles River, Queensway Bay, Long Beach 
What watershed flows near your house?
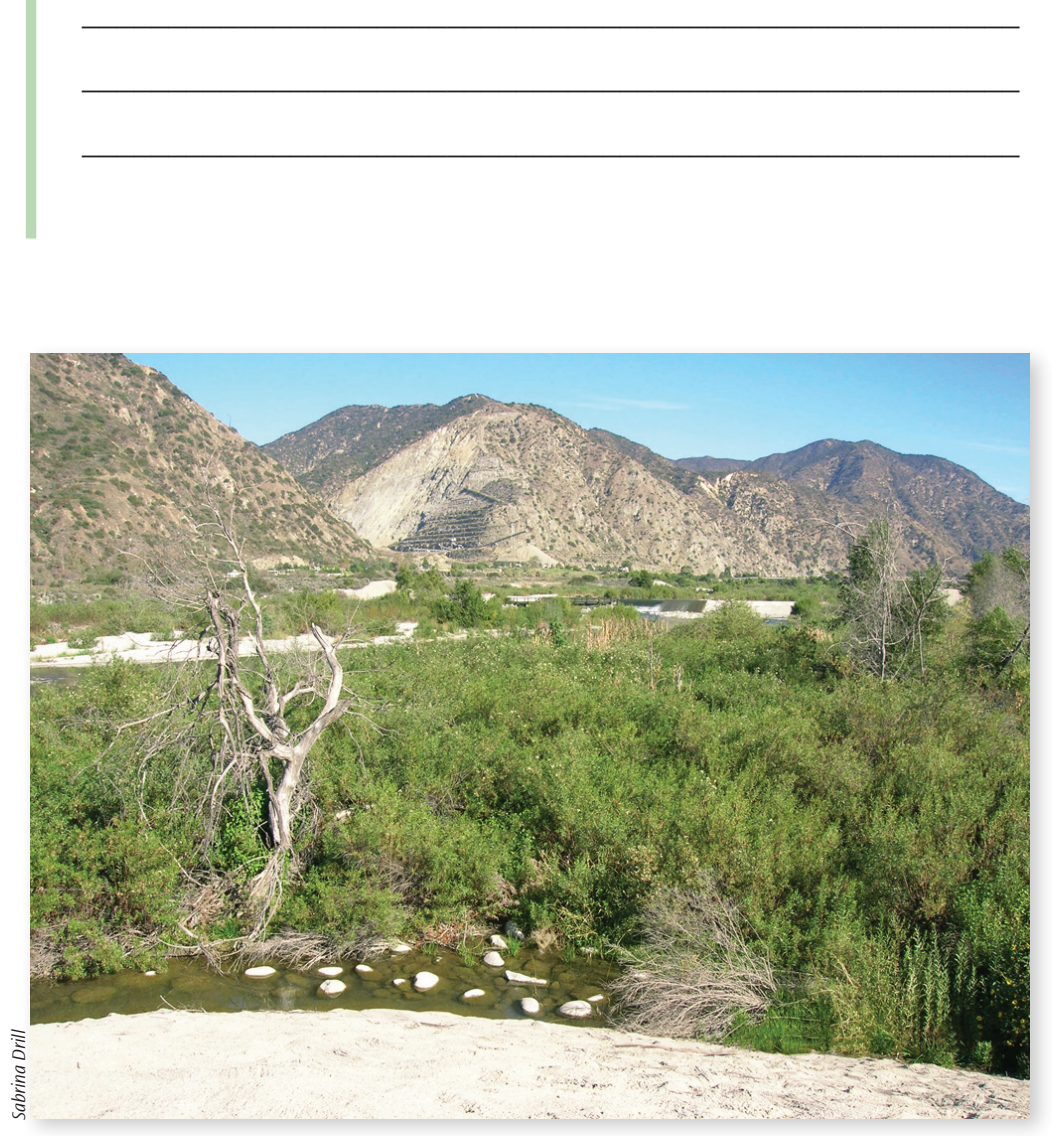

The San Gabriel River leaving the San Gabriel Mountains, NEAR DuARTe.

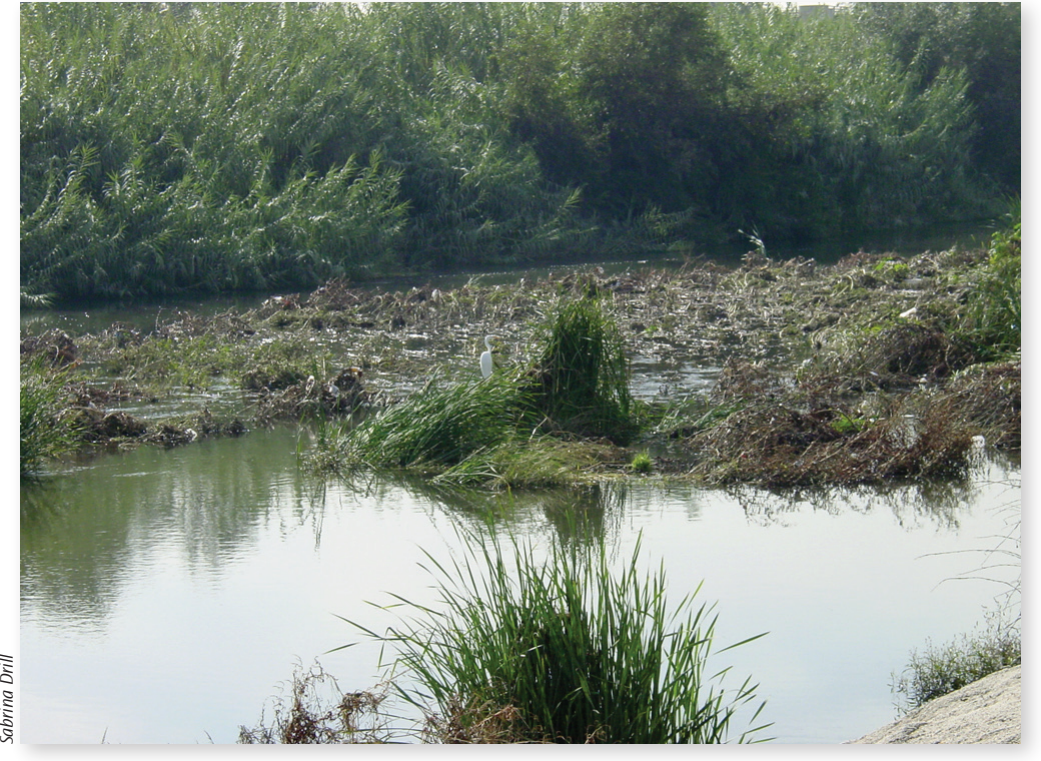

The San Gabriel River near Whittier Narrows.

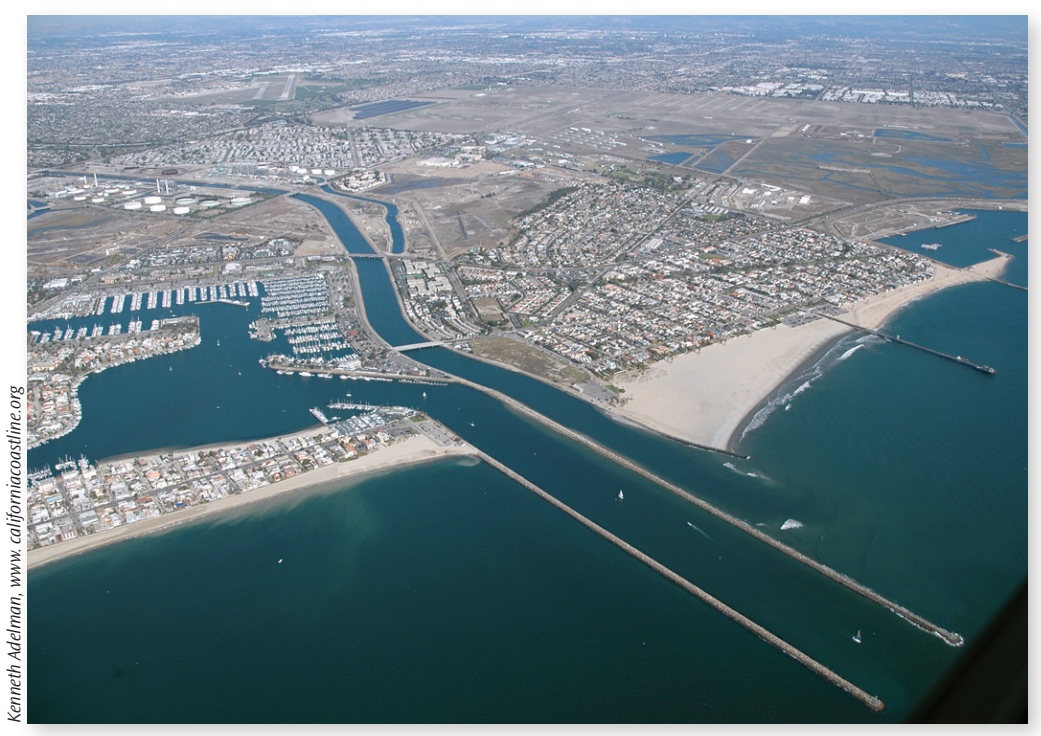

Mouth of the San Gabriel River, Alamitos Bay. 


\section{Notes}

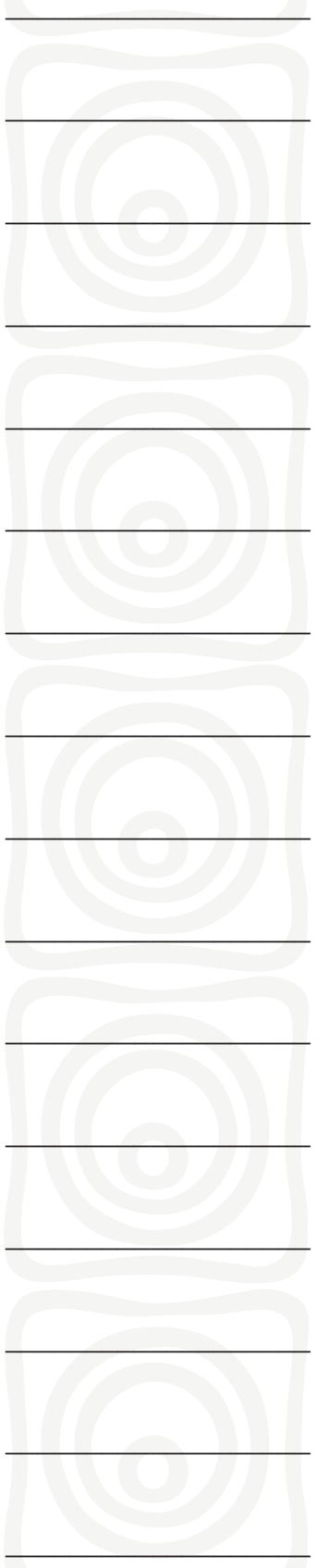

\section{Exercise 5: PROTECTING OUR WATERSHEDS}

With a partner or in a group, brainstorm a list of ways to keep watersheds clean. Then compare with the class to see who came up with the most solutions.

In a group, create a poster that you can use to educate people in your community about how to keep watersheds clean.

\section{ASSESSMENT}

Now that you have finished the lesson, how many of these questions can you answer in English?

1. What is a watershed and why is it important?

2. What is the watershed in your community called?

\section{What are some solutions for protecting watersheds?}




\section{Watersheds}

\section{Notes}

EXPANSION

\section{Writing}

Look up the word "watershed" in an English dictionary. You will find that there is more than one definition of a watershed. Once you've learned the different definitions, write, draw, or paint examples of each.

\section{Family Activity}

1. Visit these Web sites with your family:

- Center for Watershed Protection: www.cwp.org

- Heal the Bay: www.healthebay.org

- LA and San Gabriel Rivers Watershed Council: www.lasgrwc.org

-Watershed Management Council: www.watershed.org

Find out whether they have any upcoming events or meetings that you and your family can attend.

2. To find out which watershed you and your family live in, go to the "Surf your Watershed" page of the web site for the U.S. Environmental Protection Agency, http://cfpub.epa.gov/surf/locate/. Type in your zip code. What does it say? Do you have friends or relatives who live in other parts of Los Angeles, California, or other states in the United States? Type in their zip codes, and see what watershed they live in.

\section{Grammar}

Review the modal verbs "should," "must," and "have to" in statements and questions. Then give your classmates or family members advice for taking care of the watersheds in their communities. 


\section{Reducing Water Pollution}

\section{Objectives}

To define

"pollution"

To compare

point source and nonpoint source

pollution

To compare

storm drains and

sewers

To share and

learn ways to

reduce water

pollution

\section{Exercise 1: KEY VOCABULARY}

Circle the words from this list that you do not already know. Then look for synonyms or definitions in an English thesaurus or dictionary.

1. a Styrofoam cup floating in the Los Angeles River

2. oil on the road

3. a cigarette tossed into the Ventura River

4. pet waste in the street

5. fertilizers and pesticides flowing down a watershed

6. grass clippings and other trash from yardwork

New words and their definitions or synonyms:

Pollution is:

\section{Exercise 2: TWO CAUSES OF WATER POLLUTION}

\section{Paragraph 1}

"Source" means where something "Point" is an exact We use these two words to different types of pollution. There are two names for the causes of pollution: pollution and pollution.

\section{Paragraph 2}

Point source pollution is pollution that enters a body of water at a specific, location. An example of point source pollution is when chemicals from a flow into a river through a pipe, ditch, or

\section{Paragraph 3}

Nonpoint source pollution is not as easy to identify, however it is the source of pollution in the United States. Nonpoint source pollution is pollution that comes from places. When rain falls and flows on the , it picks up pollutants from different places. These pollutants include examples in the next paragraph. 


\section{Reducing Water Pollution}

\section{Notes}

\section{Paragraph 4}

- Lawn chemicals like fertilizers and and grease from cars and roads.

- Soap from your car.

- Sand and concrete from sites.

- Bacteria from pet

- Bacteria from faulty sewer systems.

\section{Paragraph 5}

As the water flows in our the pollutants enter our lakes, rivers, oceans, and eventually, our water. It is difficult to nonpoint source pollution because it begins in so many different places.

\section{Exercise 3: TWO CAUSES OF WATER POLLUTION:} SCANNING

Write the number of the paragraph from Exercise 2 next to its main idea.

Describes nonpoint pollution

Gives different types of pollutants

Defines "source" and "point"

Describes point source pollution

Explains why it is hard to resolve the problem of nonpoint

source pollution

\section{Exercise 4: SEWERS AND STORM DRAINS}

Guess whether each sentence describes a sewer or a storm drain. Under each sentence, write "sewers" or "storm drains" or "both."

Do not clean the water before taking the water into the ocean.

Clean the water many times before taking the water into the ocean

If food enters, they will attract cockroaches, rats, and flies.

Take water from bathrooms, sinks, washing machines, and toilets.

Help to prevent (avoid) flooding.

Usually begin outside on the street.

If too much trash fills them, there will be flooding.

Usually begin inside and take water from inside. 


\section{Reducing Water Pollution}

\section{Notes}

\section{Exercise 5: IS THIS A SEWER OR A STORM DRAIN?}

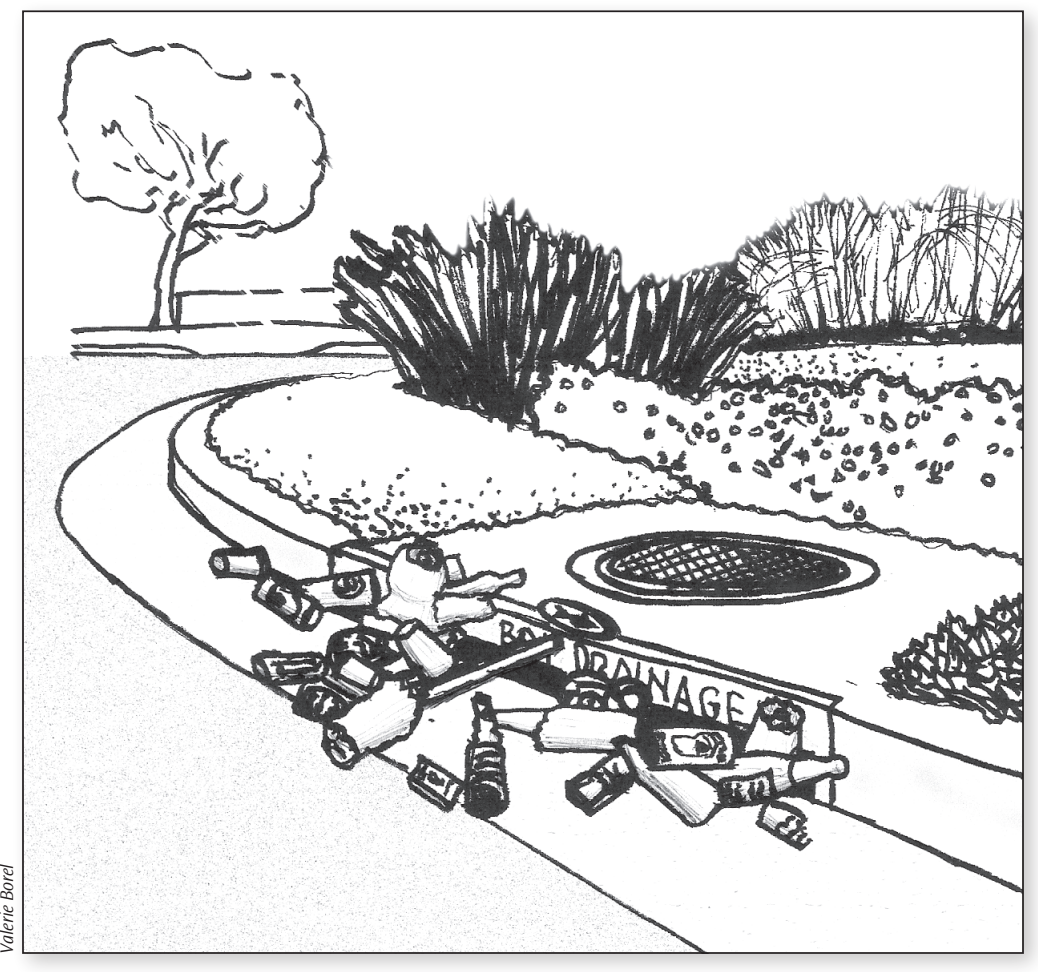

This is a:

\section{Exercise 6: LOS ANGELES STORM DRAINS}

Fill in the chart based on the information you hear in the video Make the Connection: A Video Tour of Los Angeles's Storm Drain System.

\begin{tabular}{||l||l||}
\hline Question & Answer \\
\hline $\begin{array}{l}\text { 1. According to Chris, Los Angeles } \\
\text { has been fighting ocean pollution } \\
\text { for a long time. What is the cause of } \\
\text { ocean pollution? }\end{array}$ & $\begin{array}{l}\text { A. Sewage } \\
\text { B. Natural disasters }\end{array}$ \\
\hline \hline $\begin{array}{l}\text { 2. True or False: Sewers and storm } \\
\text { drains are the same. }\end{array}$ & \\
\hline \hline $\begin{array}{l}\text { 3. Which system (storm drains or } \\
\text { sewers) does not treat waste? }\end{array}$ & \\
\hline \hline $\begin{array}{l}\text { 4. According to Chris, why is it } \\
\text { important to stop trash from } \\
\text { entering the storm drain? }\end{array}$ & $\begin{array}{l}\text { We need to stop the trash from } \\
\text { entering the storm drain or }\end{array}$ \\
\hline \hline 5. Where do storm drains start? & \\
\hline \hline
\end{tabular}




\section{Reducing Water Pollution}

\section{Notes}

2. Natara helps her dad change the oil in his car. After they take the oil out of the car, she carries the huge pan of black, thick oil to the storm drain, where she dumps it. "It's gone!" she says.

Where does the oil go next? What can Natara do instead of putting the oil into the storm drain?

1. Mr. Tran has two large trees outside his apartment building. The trees attract wasps, mosquitoes, and caterpillars. He hates the insects, so he sprays the trees with a lot of pesticide to kill them. After he sprays the pesticide, there's a big storm.

Where will the rain take the pesticides? What can Mr. Tran do instead?
3. One winter night the Horton family heard raccoons in their garbage cans outside, but it was too cold to go outside and chase them. The next morning, no one had time to clean up the garbage strewn all over the street. Later that day it rained.

What happened to the garbage on the street? What can the Horton family do instead?

4. Veronica helps her grandparents by cutting the grass in front of her house. When her grass catcher is full, she dumps her grass clippings into a nearby storm drain. There, the clippings turn yellow and begin to smell.

What will probably happen next? What can Veronica do instead? 


\section{Notes}

5. Isabel enjoys walking the family dog, Jack. When Jack needs to go to the bathroom, Isabel is careful to make Jack go along the curb so that Jack is not messing the neighbors' grass. She thinks she is helping to keep her neighborhood clean.

What will happen to the dog waste next? What can Isabel do when she walks Jack?

6. The Martin family likes to stop at fast-food restaurants on the way to the beach. They throw their bags of trash out the window so they can keep the car clean.

What can the Martin family do instead?
7. John is moving into an apartment. He wants new furniture and a new television set, and goes to a store to buy them. When he brings his new furniture and TV to his house, he puts his old sofa and television set out on the curbside. He thinks that whoever wants them can come pick them up. "Everybody does it," he says.

What will happen to the furniture and TV? What can John do instead?

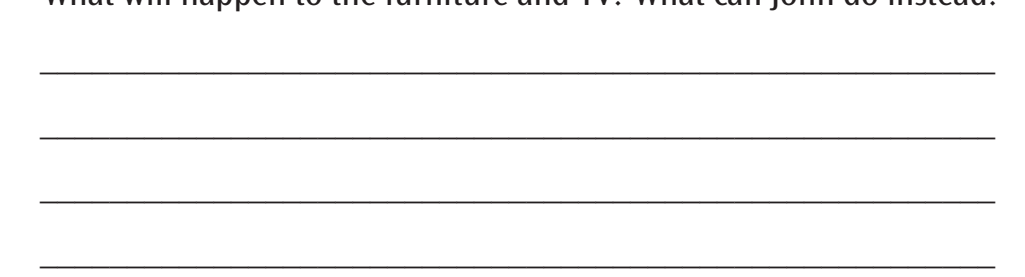




\section{Reducing Water Pollution}

\section{Notes}

\section{Exercise 8: WHO CAN YOU CALL FOR HELP?}

Research the following groups on the internet to see who in your city, county or government can help with the problems listed in Exercise 7.

The public works department can help with \#

A smart gardening workshop can help with \#

The sanitation bureau can help with \#

\section{ASSESSMENT}

How many of these questions can you answer in English?

1. What is pollution? What is the difference between "pollution," "pollutant," and "polluter"? Are you any of these? Give an example of each.

2. What is the difference between point source pollution and nonpoint source pollution? Give an example of each. Which is the biggest cause of pollution in the United States?
3. What are the similarities and differences between sewers and storm drains? Describe Los Angeles's storm drains.

4. Name five ways to reduce water pollution. Name three resources to search for more information about reducing water pollution.

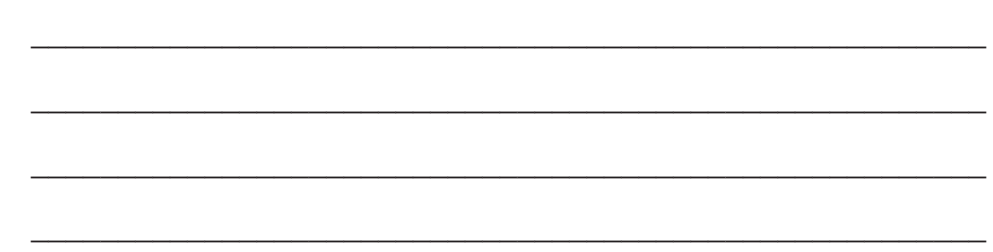




\section{Reducing Water Pollution}

Notes

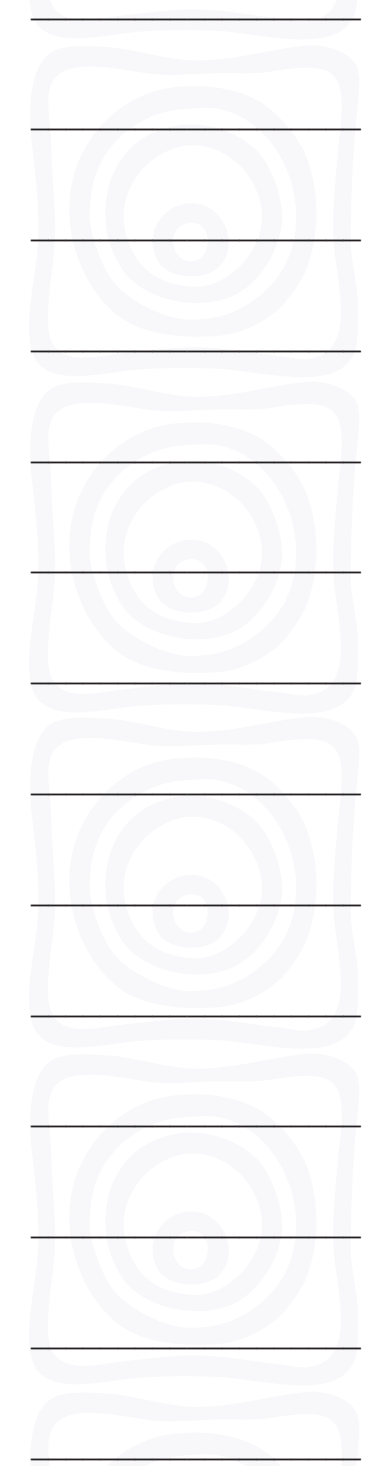

\section{EXPANSION}

\section{Writing}

Reread your first writing called "My Favorite Body of Water." Are there any changes you would make to it? If so, write a new one with those changes. If not, think about water pollution in the country where you were born and write about that. Is the water cleaner in the country where you were born than in your community here? Do you feel that the people in the country where you were born know more or less about keeping water clean than most Americans? Do you think that it is possible for you to help keep water clean in your current community? In the state you live in now? In the world?

\section{Family Activity}

1. Coastal Cleanup Day: What can you do to clean up rivers and beaches? You can participate in Coastal Cleanup Day in midSeptember, when Californians gather on the beaches and rivers to clean up. Events for Coastal Cleanup Day can be found on the California's Coastal Commission Web site, http://www.coastal.ca.gov/ publiced/ccd/ccd.html.

2. Earth Day: Earth Day is celebrated every year in the third week of April. Look for events all over California in the newspapers during that time.

\section{Grammar}

Review the conditional for hypothetical situations. Discuss what would happen if people continue to pollute water. 
agriculture The occupation, business, or science of cultivating the land, producing crops, and raising livestock.

antonym A word that means the opposite of another word.

aqueduct A pipe or channel for moving water.

bay An area of sea enclosed by a wide inwardcurving stretch of coastline.

$\operatorname{brook}(\boldsymbol{n}) \quad$ A small freshwater stream.

channel $(\boldsymbol{n}) \quad$ A long, narrow passage or tube along which a liquid can flow.

chemical $(\boldsymbol{a d j})$ Produced by or involved in the processes of chemistry.

\section{coastline Shoreline}

concrete $(\boldsymbol{n}) \quad$ A hard construction material.

conserve To keep something, especially an important environmental or cultural resource, from harm, loss, change, or decay.

$\operatorname{creek}(\boldsymbol{n}) \quad$ A small body of moving water.

desirable Worth having or doing.

drain $(\boldsymbol{v}) \quad$ To flow out of something, often leaving it empty or dry.

drinkable Safe for humans or animals to drink east

faucet

fertilize

An area of low-lying land that is frequently flooded.

freshwater Water that does not contain salt.

gallon

A unit of capacity in the U.S. Customary system equal to eight U.S. pints (approximately 3.79 liters).

gutter

lake

lagoon

leak $(v)$

A channel at the edge of a road that carries water into a drain.

A large body of water surrounded by land.

A body of shallow water close to the open sea, but separated from the sea at least part of the time.

To let something (such as water) escape accidentally.

map features Details on a map that represent different locations. marsh

native

An area of land, often beside water, that is poorly drained and liable to flood, and that is unfit for agriculture or building.

nonpoint source pollution pollution caused by many sources.

north The direction that lies to the left of someone facing the rising sun.

ocean

A very large body of salt water that covers most of the earth and can be divided into five parts (Atlantic, Pacific, Indian, Southern, and Arctic).

pesticide A chemical used to kill pests. Pesticides that kill insects are also called insecticides

pet waste Excrement from a pet.

point source pollution Pollution that is caused by only one source.

polluted Contaminated.

pollution The condition of being polluted, or the presence of pollutants.

pond $(\boldsymbol{n}) \quad$ A small still body of water formed naturally or created artificially.

potable
Suitable for drinking because it contains no harmful elements. 
proverb

A short, well-known saying that expresses an obvious truth and often offers advice.

river

A large body of fresh, moving water.

saltwater (adj) Relating to a body of water containing salt.

scan $(v) \quad$ To look through or read something quickly

sea

A large body of water totally or partially enclosed by land.

sewer A pipe or drain, usually underground, that carries away waste or rainwater.

soak To make something or someone completely wet.

south The direction that lies to the right of someone facing the rising sun.

spring ( $\boldsymbol{n}$ ) A small body of water that flows out of the ground.

storm drain A system for draining rain and groundwater into a large body of water.

stream ( $\boldsymbol{n}) \quad$ A body of moving water.

Styrofoam A light plastic material used to make disposable items.

synonym

A word that means the same or almost the same as another word.

thesaurus A book that lists synonyms and antonyms.
Extremely important or necessary.

waterfall

A vertical stream of water falling from the edge of a steep place.

watershed

The land area that drains into a particular body of water.

west 